\title{
HPLC determination of hydrochlorothiazide in urine after solid-phase extraction
}

\author{
Violeta Ivanova $^{1}$, Dragica Zendelovska ${ }^{2}$ and Marina Stefova ${ }^{1 *}$ \\ ${ }^{1}$ Institute of Chemistry, Faculty of Science, \\ ${ }^{2}$ Institute of Preclinical and Clinical Pharmacology and Toxicology, Medical Faculty, \\ Sts. Cyril and Methodius University, Skopje, Republic of Macedonia
}

Received April 2005, accepted June 2005

\begin{abstract}
A simple, rapid and precise HPLC method has been developed for the assay of hydrochlorothiazide in urine. The clean-up of the urine samples was carried out by solid-phase extraction using HLB cartridges. Extraction recovery was 94.00-100.28 \%. HPLC separation was performed with isocratic elution on Hypersil BDS C18 column (100 x 4.0 mm I.D., $3 \mu \mathrm{m}$ particle size) protected with appropriate guard column. The mobile phase was $18 \%$ acetonitrile and $0.025 \mathrm{~mol} / \mathrm{L}$ solution of $\mathrm{KH}_{2} \mathrm{PO}_{4}, \mathrm{pH} 4$ at flow rate of $0.3 \mathrm{~mL} / \mathrm{min}$. Detection of the substances was performed at $220 \mathrm{~nm}$. The calibration curves were linear in the range of 2-50 $\mu \mathrm{g} / \mathrm{mL}$. The developed method is validated by checking its accuracy, precision and stability. The detection limit is $2 \mu \mathrm{g} / \mathrm{mL}$ hydrochlorothiazide. The method is proved to be convenient for routine analysis of hydrochlorothiazide in urine.
\end{abstract}

Keywords: Hydrochlorothiazide, urine, solid-phase extraction, HPLC

\section{Introduction}

Hydrochlorothiazide is a thiazide diuretic drug (Fig. 1), which is used in treatment of hypertension, either alone or together with other agents, it is effective in treatment of congestive heart failure and hepatic disorders. In medical practice, it is mostly used in a conventional tablet form in dose of 25 to $250 \mathrm{mg}$ (1).

Several investigations have been performed for determination of hydrochlorothiazide in urine by high-performance liquid chromatography (HPLC) with UV detection and electrochemical detection. Zendelovska and Stafilov (2) published a review of HPLC methods for determination<smiles>NS(=O)(=O)c1cc2c(cc1Cl)NCNS2=O</smiles>

Fig. 1. Structure of hydrochlorothiazide

\footnotetext{
*Correspondence: marinaiv@iunona.pmf.ukim.edu.mk
}

of diuretics in biological fluids including procedures for sample preparation. Liquid-liquid extraction with different organic solvents is mostly used for determination of hydrochlorothiazide in urine. But, in this way, separation of hydrochlorothiazide from interferential components is not achieved and recovery values are poor. Cooper and coworkers (3) suggested a liquid-liquid extraction of hydrochlorothiazide from urine and serum by ethyl acetate and back extraction with sodium hydroxide, but recovery values were $91,5 \pm 2,5 \%$. Shiu and coworkers (4) proposed a liquid-liquid extraction of hydrochlorothiazide from urine with ethyl acetate, but again, the recovery values are ranged from 62.2 to $80.7 \%$. Alton and coworkers (5) have also used ethyl acetate for extraction of hydrochlorothiazide from urine.

On the other hand, Domingo and coworkers (6) used micellar liquid chromatography for determination of hydrochlorothiazide in urine by direct injection of sample in the chromatographic system without any sample pretreatment. Zendelovska and coworkers (7) developed a solid-phase extraction method for determination of hydrochlorothiazide in human plasma. Papadoyannis and coworkers $(8,9)$ have performed a chromatographic deter- 
mination of cephalosporin antibiotics in biological fluids and pharmaceuticals using hydrochlorothiazide as an internal standard. The confirmation technique most widely used is GC/MS, which requires methylation of the aminosulfonyl group followed by GC/MS measurement (10).

The purpose of this study was to develop and validate a liquid chromatographic method with UV detection suitable for the determination of hydrochlorothiazide in urine. A new solid-phase extraction method was developed using HLB cartridges. This is a convenient method for separation and concentration of the analyzed drug and elimination of urine interferences, because of its efficiency and rapid sample preparation. The method was validated by evaluating the recovery, selectivity, linearity, precision and accuracy. Finally, the method was used for determination of hydrochlorothiazide in urine samples from patients.

\section{Experimental}

\subsection{Materials and reagents}

Hydrochlorothiazide was kindly provided from Changzhou Pharmaceutical Factory (China). Acetonitrile, methanol, phosphoric acid, and potassium dihydrogen phosphate were from Merck (Darmstadt, Germany). All solvents used were of HPLC grade. HPLC column was purchased from Hewlett Packard and cartridges for solid-phase extraction were purchased from Waters.

\subsection{Preparation of standards}

Stock solution of hydrochlorothiazide was prepared at concentration of $2 \mathrm{mg} / \mathrm{mL}$ by dissolving appropriate amounts of hydrochlorothiazide in methanol. The working solutions were prepared by diluting appropriate portions of this solution with redistilled water and stored at $4{ }^{\circ} \mathrm{C}$.

\subsection{Instrumentation and HPLC analysis}

Analysis of hydrochlorothiazide was carried out with a Varian HPLC system equipped with a ternary pump Model 9012 and UV Diode Array Detector Model 9065. Satisfactory results (peak shape and run time) were obtained with Hypersil BDS C18 column (100 x 4.0 mm I.D., $3 \mu \mathrm{m}$ particle size) protected with appropriate guard column. A mobile phase consisting of solution of $\mathrm{KH}_{2} \mathrm{PO}_{4}$ with concentration $0.025 \mathrm{~mol} / \mathrm{L}(\mathrm{pH} 4)$ and $18 \%$ acetonitrile was found to give the best results. Isocratic elution was performed with flow rate of $0.3 \mathrm{~mL} / \mathrm{min}$ at ambient temperature. Elution was monitored in the whole UV region and the best detection was achieved on wavelength of $220 \mathrm{~nm}$.

Solid-phase extraction was performed with the device (SPE) Visiprep ${ }^{\mathrm{TM}}$ from Supelco.

\subsection{Sample preparation}

Urine samples were collected from healthy volunteers and stored at $-20^{\circ} \mathrm{C}$. After thawing, samples were spiked daily with working solutions of hydrochlorothiazide. Several cartridges with different stationary phases for SPE were tested: LiChrolut RP-18 (Merck), LC-18 (Supelco) and Oasis HLB (Waters). Best results for isolation of hydrochlorothiazide were obtained when SPE was performed with Oasis HLB cartridges.

Before extraction, $1 \mathrm{~mL}$ of urine sample was buffered with $1 \mathrm{~mL}$ of $0.1 \mathrm{~mol} / \mathrm{L} \mathrm{KH}_{2} \mathrm{PO}_{4}$ solution, $\mathrm{pH}$ 9. The cartridges were conditioned with $1 \mathrm{~mL}$ methanol and $1 \mathrm{~mL}$ redistilled water. The buffered urine was introduced into the cartridge. $1 \mathrm{~mL}$ of redistilled water was used to rinse the cartridge and remove the interfering components. Elution was performed with $1 \mathrm{~mL}$ methanol. The eluate was evaporated to dryness under air for about $15 \mathrm{~min}$ at $40-45^{\circ} \mathrm{C}$. Reconstitution was performed with $200 \mu \mathrm{L}$ mobile phase and $20 \mu \mathrm{L}$ sample was injected into the HPLC system.

\subsection{Calibration standards}

Linear regression analysis was performed. Typical calibration curves were constructed with five blank urine samples spiked with appropriate amounts of the standard solution of hydrochlorothiazide. The calibration range was $2-50 \mu \mathrm{g} / \mathrm{mL}$ of hydrochlorothiazide in urine. Three quality control standards containing 7, 15 and $30 \mu \mathrm{g} / \mathrm{mL}$ hydrochlorothiazide in urine were used for precision and accuracy measurements.

\section{Results and discussion}

\subsection{Method development}

In order to develop a convenient, simple and rapid HPLC method for quantitative determination of hydrochlorothiazide in urine, several HPLC method variables with respect to their effect on the place and shape on the peak of hydrochlorothiazide, were investigated. The optimization of the HPLC conditions was performed for hydrochlorothiazide and cefotaxime, which was tested as an internal standard. Symmetrical shape of the peaks and relatively short time for analysis were obtained when separation was performed on Hypersil BDS C18 column $(100 \times 4.0$ mm I.D., $3 \mu \mathrm{m}$ particle size) protected with appropriate guard column with flow rate of $0.3 \mathrm{~mL} / \mathrm{min}$ flow rate. The elution was monitored in the whole UV region and the wavelength of $220 \mathrm{~nm}$ exhibited the best detection of hydrochlorothiazide due to an absorption maximum at this wavelength.

Series of mobile phases with variable content of the organic modifier acetonitrile in range from 15 to $30 \%$ were prepared in order to investigate its effect on hydrochloro- 
thiazide and cefotaxime retention. Satisfactory results (peak shape, short retention time) were obtained when the volume fraction of acetonitrile in the mobile phase was $18 \%$.

Additionally, the effect of the buffer concentration on analyte retention was investigated in the concentration range from 0.0125 to $0.0500 \mathrm{~mol} / \mathrm{L}$. Best results were achieved with solution of $\mathrm{KH}_{2} \mathrm{PO}_{4}$ with concentration of $0.025 \mathrm{~mol} / \mathrm{L}$. The subsequent increasing of the buffer concentration caused increase in analysis time. Therefore, all following investigations were performed with a mobile phase, containing $\mathrm{KH}_{2} \mathrm{PO}_{4}$ with concentration of $0.025 \mathrm{~mol} / \mathrm{L}$ and $18 \%$ acetonitrile.

The effect of the $\mathrm{pH}$ value on the hydrochlorothiazide and cefotaxime retention was also checked by elution with mobile phases with $\mathrm{pH}$ in the range from 2.2 to 4.5. A mobile phase with $\mathrm{pH} 4$ provided a short analysis time and good peak shape.

Finally, the effect of temperature on retention of the analyzed component was checked in the range from 20 to $50^{\circ} \mathrm{C}$. The obtained results showed that temperature does not affect the peak shape and analysis time significantly, so ambient temperature was chosen for all investigations.

From these data it was established that the best results (satisfactory retention, acceptable runtime less than 6.5 min.) were obtained using mobile phase consisting of $18 \%$ acetonitrile in solution of $\mathrm{KH}_{2} \mathrm{PO}_{4}$ with concentration of $0.025 \mathrm{~mol} / \mathrm{L}$ and $\mathrm{pH} 4$. The retention time of hydrochlorothiazide is $5.8 \mathrm{~min}$ and $4.0 \mathrm{~min}$ for cefotaxime. Typical chromatogram obtained from standard solution of hydrochlorothiazide and cefotaxime produced by the developed HPLC method is shown in Fig. 2.

Calibration diagram was constructed for establishing the dependence of the peak area of hydrochlorothiazide and concentration. The obtained linear dependence of peak area of hydrochlorothiazide and mass concentration of hydrochlorothiazide in pure solutions, with correlation coefficient (0.9999) is the following:

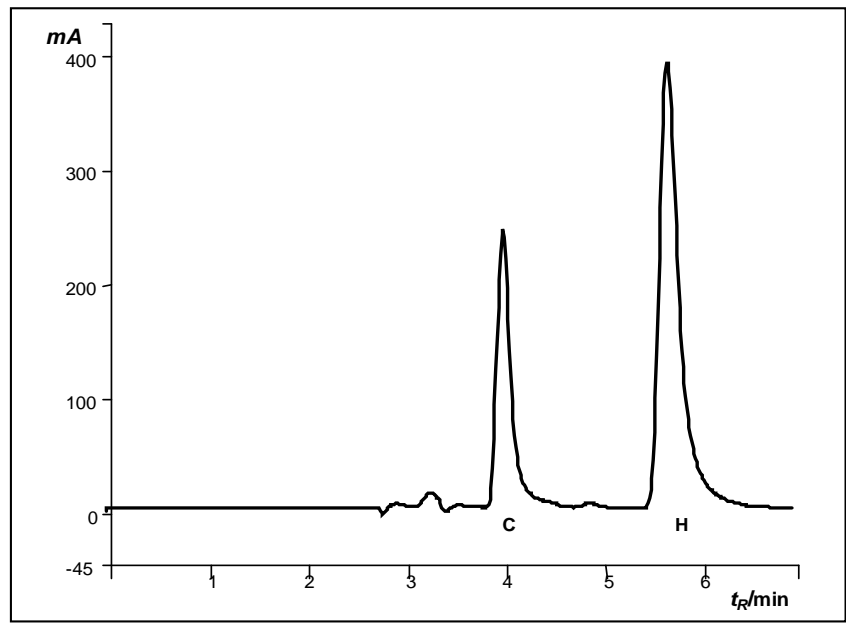

Fig. 2. Chromatogram of standard solution of hydrochlorothiazide $(8 \mu \mathrm{g} / \mathrm{mL})$ and cefotaxime $(8 \mu \mathrm{g} / \mathrm{mL})$

$$
\operatorname{Area}(\mathrm{H})=194029 \cdot \gamma(\mathrm{H})(\mu \mathrm{g} / \mathrm{mL})+297658
$$

As previously said, several cartridges for solid-phase extraction (LiChrolut RP-18 (Merck), LC-18 (Supelco) и Oasis HLB (Waters)) were tested in order to obtain satisfactory values for recovery of hydrochlorothiazide from urine samples. Results from this investigation show satisfactory values for recovery of hydrochlorothiazide when urine samples were extracted on Oasis HLB (Waters) cartridges. The values obtained for recovery of hydrochlorothiazide ranged from 94.00 to $100.28 \%$. The chromatographic peak is sharp, with relatively symmetric shape with small tailing, well separated form the matrix components present in the urine (Fig. 3). In this phase, cefotaxime was excluded as a possible internal standard because of its poor separation from the endogenous compounds from urine and the method was then validated using HLB cartriges for sample preparation and the optimized HPLC conditions for measurement using calibration with an external standard of hydrochlorothiazide.

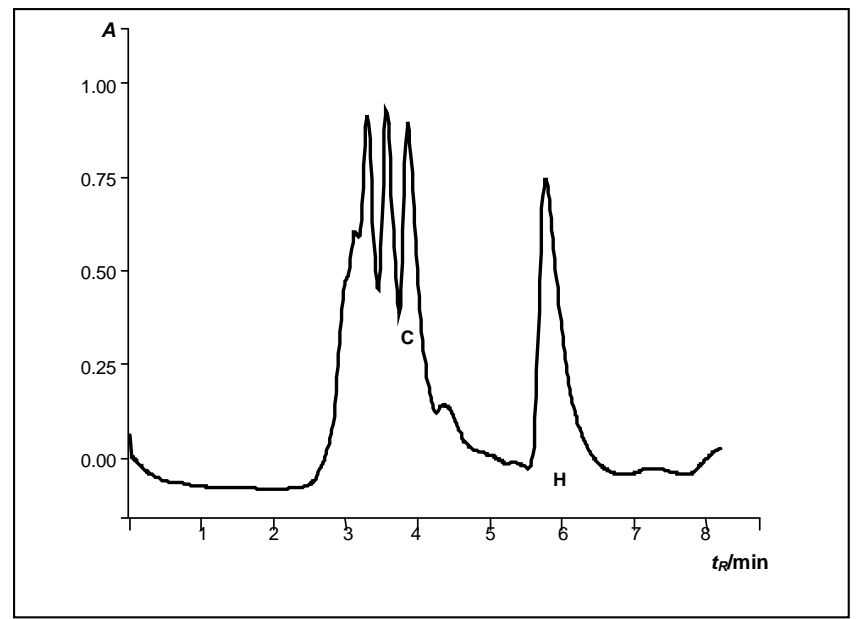

Fig. 3. Chromatogram of urine sample spiked with hydrochlorothiazide $(25 \mu \mathrm{g} / \mathrm{mL})$ obtained after SPE on HLB columns

Separation of interferential components from matrix was not achieved with application of RP-18 cartridges for solid-phase extraction of hydrochlorothiazide and a loss of analyzed component during the washing step was noticed. LC-18 cartridges were not convenient for separation of the analyzed component from matrix components present in urine. Endogenous components from urine were not eliminated and the chromatographic peak of hydrochlorothiazide was overlapped with chromatographic peaks of the interferential endogenous components. 
Table 1. Intra- day and inter- day accuracy and precision data for hydrochlorothiazide in urine determined with solid-phase extraction

\begin{tabular}{|c|c|c|c|c|c|c|}
\hline & \multicolumn{3}{|c|}{ Intraday precision and accuracy } & \multicolumn{3}{|c|}{ Interday precision and accuracy } \\
\hline & $\begin{array}{c}<\gamma>/ \mu g / m L \\
n=3\end{array}$ & $R S D(\%)$ & $\begin{array}{l}e_{\mathrm{r}} \\
(\%)\end{array}$ & $\begin{array}{c}<\gamma>/ \mu \mathrm{g} / \mathrm{mL} \\
n=6\end{array}$ & $R S D(\%)$ & $\begin{array}{c}e_{\mathrm{r}} \\
(\%)\end{array}$ \\
\hline $7 \mu \mathrm{g} / \mathrm{mL}$ & 6.84 & 1.03 & -2.24 & 6.86 & 5.16 & -1.90 \\
\hline $15 \mu \mathrm{g} / \mathrm{mL}$ & 15.03 & 1.01 & 0.22 & 15.28 & 4.42 & 1.85 \\
\hline $30 \mu \mathrm{g} / \mathrm{mL}$ & 29.96 & 2.77 & -0.13 & 30.05 & 3.61 & 0.16 \\
\hline
\end{tabular}

\subsection{Method validation}

\subsubsection{Linearity}

Linearity was tested in 3 days at five concentration points ranging from 2 to 50 ?g/mL of hydrochlorothiazide. The following values for the slope, intercept, and correlation coefficient were obtained:

Slope $=184199.4 \quad$ Intercept $=-46177.9 \quad \mathrm{R}^{2}=0.99977$

\subsubsection{Accuracy and precision}

Intra-and inter-day precision and accuracy were determined by measuring urine quality control samples at low $(7 \mu \mathrm{g} / \mathrm{mL})$, middle $(15 \mu \mathrm{g} / \mathrm{mL})$ and high $(30 \mu \mathrm{g} / \mathrm{mL})$ concentration levels of hydrochlorothiazide. An indication of accuracy was based on calculation of the relative error of the mean observed concentration compared with the nominal concentration. Precision was expressed as relative standard deviation (RSD). Obtained results are presented in Table 1.

Relative errors ranged from 0.26 to $9.28 \%$, and relative standard deviation from 1.01 to $5.16 \%$. The obtained results indicated good precision and accuracy of the developed method.

\subsubsection{Limit of quantification ( $L O Q$ )}

The limit of quantification is defined as the lowest concentration of hydrochlorothiazide which can be measured with an error less than $20 \%$. The LOQ was determinated using the lowest calibration standard in five different analytical days. The RSD value of $7.57 \%$ and a relative error less than $10 \%$ confirmed that the hydrochlorothiazide concentration of $2 \mu \mathrm{g} / \mathrm{mL}$ in urine can be accepted as LOQ.

\subsubsection{Stability of hydrochlorothiazide in urine samples}

The stability of hydrochlorothiazide in urine samples was investigated with spiked samples at two different concentration levels prepared in duplicate. Spiked samples were analyzed after different storage conditions: immediately, after staying for 2 and 24 hours at room temperature, after one and two freeze/thaw cycles and after 1 month stored at $-20^{\circ} \mathrm{C}$. The obtained results form these investigations are shown in Table 2.

Table 2. Stability of hydrochlorothiazide in urine

$\begin{array}{ccccc}\begin{array}{c}\text { Analyzed } \\ \text { samples }\end{array} & \begin{array}{c}7 \\ \mu \mathrm{g} / \mathrm{mL}\end{array} & \begin{array}{c}e_{\mathrm{r}} \\ (\%)\end{array} & \begin{array}{c}30 \\ \mu \mathrm{g} / \mathrm{mL}\end{array} & \begin{array}{c}e_{\mathrm{r}} \\ (\%)\end{array} \\ \text { Immediately } & 6.98 & -0.28 & 29.48 & -1.73 \\ \text { After 2h } & 6.72 & -3.72 & 30.95 & 4.98 \\ \text { After 24h } & 6.85 & -1.86 & 29.42 & -0.20 \\ \text { Cycle 1 } & 7.02 & 0.57 & 31.12 & 5.56 \\ \text { Cycle 2 } & 7.23 & 3.58 & 27.83 & -5.59 \\ \text { After 1 month } & 7.13 & 2.14 & 30.19 & 2.41\end{array}$

The obtained results show that relative errors are between 0.28 to $5.59 \%$, which means that, hydrochlorothiazide added in urine samples is stable under different storage conditions.

\subsubsection{Ruggedness of the method}

Ruggedness of the method was checked by employing the proposed HPLC method with slightly changed $\mathrm{pH}$ value of the mobile phase and by using slightly changed detection wavelength. The relative error was calculated by comparing the results obtained with the optimized conditions and the ones obtained with the slightly changed parameters ( $\mathrm{pH}$ value of the mobile phase from 3.7 to 4.3, detection wavelength 215 and $224 \mathrm{~nm}$ ). For this test, a standard solution with medium concentration of hydrochlorothiazide $(7 \mu \mathrm{g} / \mathrm{mL})$ was directly injected into the HPLC system. Results are present in Table 3.

The relative errors between 0.08 and $4.77 \%$ indicating ruggedness of the developed HPLC method when using

Table 3. Ruggedness of the method for hydrochlorothiazide at slightly varied $\mathrm{pH}$ values and detection wavelengths

$\begin{array}{lcc}\text { Sample } & \begin{array}{c}7 \mu \mathrm{g} / \mathrm{mL} \\ \\ \end{array} & \\ & \text { Area }> & e_{\mathrm{r}}(\%) \\ 220 \mathrm{~nm} & 2058948 & \\ 215 \mathrm{~nm} & 1999378 & -2.89 \\ 224 \mathrm{~nm} & 2137594 & 3.82 \\ \text { pH 2.5 } & 2058948 & \\ \text { pH 2.2 } & 2075528.3 & 0.81 \\ \text { pH 2.8 } & 1990904 & -3.30\end{array}$

Maced. pharm. bull., 51, (1,2) 23-28 (2005) 
slightly variable $\mathrm{pH}$ values of the mobile phase. The results presented in Table 3, show that little changes in the detection wavelength produce relative errors in the range from 1.09 to $4.87 \%$ which confirms the ruggedness of the SPE method developed for solid-phase extraction of hydrochlorothiazide.

The developed HPLC method after solid-phase extraction of hydrochlorothiazide from urine was used for analysis of patient urine samples after oral administration of the analyzed drug. Typical chromatograms obtained from urine samples prepared according to the developed procedure for sample preparation are shown in Fig. 4.

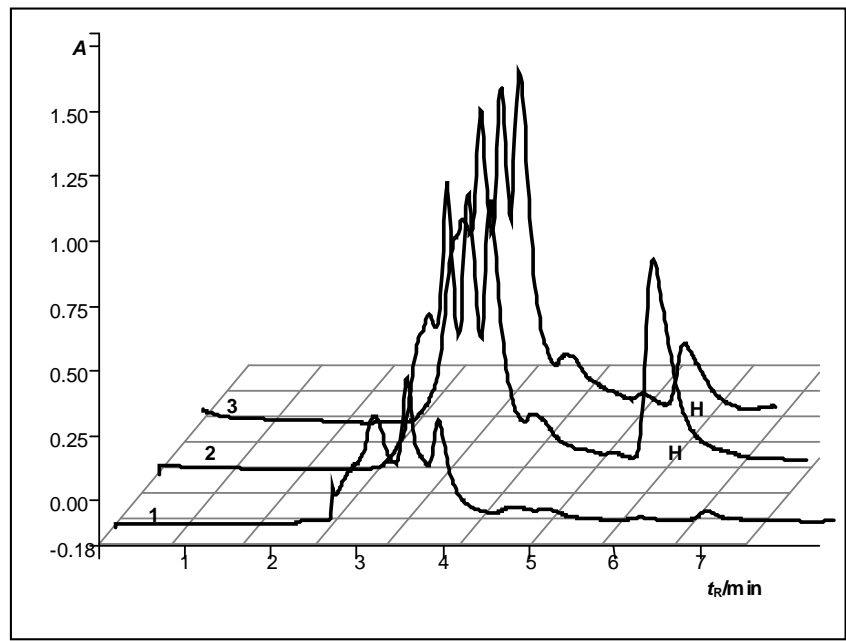

Fig. 4 Chromatograms obtained after SPE of:

1 - blank sample, 2 - spiked urine containing $25 \mu \mathrm{g} / \mathrm{mL}$ hydrochlorothiazide and 3 - patient urine sample (H - hydrochlorothiazide)

\section{Conclusion}

The HPLC method including solid-phase extraction for sample preparation is simple, rapid and convenient for determination of hydrochlorothiazide in urine samples. HPLC conditions are optimized as well as the sample preparation procedure. Different SPE cartridges for separation and concentration of hydrochlorothiazide were tested and best results are obtained with HLB cartridges. SPE conditions with HLB cartriges are optimized for separation of hydrochlorothiazide and efficient clean up of the complex biological matrix and high recovery of the investigated drug is achieved. The validation data demonstrate good precision and accuracy, which proves the reliability of the proposed method. Finally, this method is suitable for identification and quantification of hydrochlorothiazide in urine and it can be used in pharmacological studies.

\section{References}

1. Martindale, The Extra Pharmacopoeia, 31st ed., Royal Pharmaceutical Society, London, 186-190 (1996).

2. D. Zendelovska, T. Stafilov, Acta Pharm, 52(2), (2006).

3. M. J. Copper, A. R. Sinalko, M. W. Anders, B. L. Mirkin, Anal. Chem., 48(8), 1110-1111 (1976).

4. G. K. Shiu, V. K. Prasad, J. Lin, W. Worsley, J. Chrom. Biomed. Appl., 377, 430-435 (1986).

5. K. B. Alton, D. Desrivieres, J. E. Patric, J. Chromatogr., 374, 103-110 (1986).

6. E. B. Domingo, M. J. M. Hernandez, G. R. Ramos, M. C. G. Alvarez-Coque, J. Chromatogr., 582, 189-194 (1992).

7. D. Zendelovska, T. Stafilov, P. Milosevski, Biomed. Chromatogr., 18, 71-76 (2004).

8. V. F. Samanidou, E. A. Hapeshi, I. N. Papadoyannis, J. Chromatogr. B, 788, 147-158 (2003).

9. V. F. Samanidou, A. S. Ioannou, I. N. Papadoyannis, J. Chromatogr. B, 809, 175-182 (2004).

10. A. M. Lisi, R. Kazlauskas, G. J. Trout, J. Chromatog. B: Boimed. App., 581, (1) 57-63 (1992). 


\section{Резиме \\ HPCL определување на хидрохлортиазид во урина после цврстофазна естракција \\ Виолета Иванова ${ }^{1}$, Драгица Зенделовска², Марина Стефова ${ }^{1 *}$

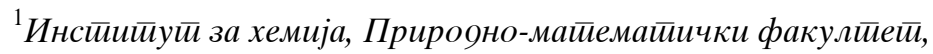

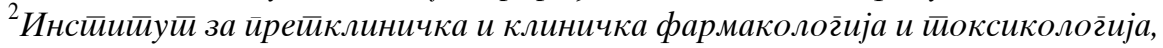

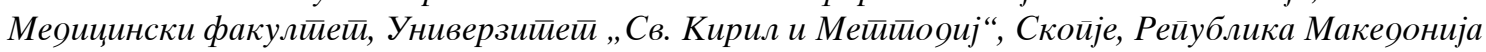

Клучни зборови: хидрохлортиазид, урина, цврстофазна, екстракција, HPCL.

Развиен е едноставен, брз и прецизен HPCL метод за определување на содржина на хидрохлортиазид во урина. Подготовката на примероците од урина и нивно прочистување е направено со HLB колони од цврстофазна екстракција. Приносот по пречистувањето е 94,00 - 100,28\%. Раздвојуувањето на компонентите е направено со искратско елуирање на Hypersil BDS C18 колона (100 x 4,0 mm, I.D., 3 m големина на честички) со соодветна предколона. Мобилна фаза во состав: $18 \%$ ацетонитрил и $0,02 \mathrm{~mol} / \mathrm{L}$ раствор на $\mathrm{KH}_{2} \mathrm{PO}_{4}, \mathrm{pH} 4$ и проток на $0,3 \mathrm{~mL} / \mathrm{min}$. Детекцијата на супстанците е извршена на $220 \mathrm{~nm}$. Калибрационата крива покажува линеарност во опсегот од $2-50 \mu \mathrm{g} / \mathrm{mL}$. Методот е валидиран со проверка на точност, прецизност и соодветност на системот. Лимитот на детекција е $2 \mu \mathrm{g} / \mathrm{mL}$ хидрохлортиазид. Овој метод веќе ја има докажано својата едноставност и употребливост во рутинска анализа на хидрохлортиазид. 